\title{
EVALUATION OF DENTAL PLAQUE REMOVAL PROCEDURE IN ADULT POPULATION FROM THE LOMŻA REGION
}

\author{
OCENA WYKONYWANIA PROCEDUR USUWANIA ZŁOGÓW NAZĘBNYCH \\ U DOROSŁYCH OSÓB Z MIASTA ŁOMŻY I OKOLIC
}

\author{
${ }^{1}$ Praktyka Stomatologiczna, Łomża, Poland \\ ${ }^{2}$ DentalClinic Ursynów Stokłosy, Warsaw, Poland \\ ${ }^{1}$ Centrum Stomatologiczne Demed w Łomży, \\ ${ }^{2}$ Lecznica Ursynów Stokłosy w Warszawie
}

\begin{abstract}
INTRODUCTION. The National Health Fund guarantees to insured persons free dental treatment as part of a catalog of scopes and benefits, such as dental treatment. Among the services included in the appendix there is a dental plaque removal procedure, which can be performed in adults once every 12 months or once every 6 months in the case of pregnant and puerperal women. This procedure involves breaking down the bacterial biofilm above and below the gingiva, rinsing it in vases with water from the periodontal area, and additionally, through the cavitation effect, it causes the implosion of air bubbles, directly destroying bacterial cells.

MATERIALS AND METHODS. The analysis covered 2,114 patients aged 18-89 who visited the dentist from 01/01/2019 to 31/12/2019. The dental clinic was located in a medium-sized town in the Podlaskie Voivodeship. The dental plaque removal procedures were performed on patients by dentists and then coded in accordance with the ICD9 Basic Edition Dictionary ICD9 CM (5.18) "23.1601 - Removal of plaque from 1/2 of the dental arch", respectively. The visits analyzed for this study were performed in the period from 01/01/2019 to 31/12/2019. In the following epidemiological descriptive study, secondary sources of information were used, in the form of collective reports generated from electronic records, which are stored in the dental clinic that provides dental care for patients under an agreement with the National Health Fund for general dental treatment.

RESULTS. The total number of women undergoing the plaque removal procedure was significantly higher than the number of men. The distribution of patients in different age groups was uneven. The highest percentage of patients undergoing the dental plaque removal procedure occurred in the age groups of 18-29 and 30-39 years - $21 \%$ and $29 \%$ of all respondents, respectively. The lowest number of patients was found in the age group of $80-89$ years (1\%).There is a statistical difference in the total number of dental procedures and in each age group in favor of women in each group, except the 60-79 age group. The greatest number of dental plaque removal procedures, compared to other procedures, was performed in men aged 30-39 years. Among men, along with the increase in age up to the age of 60 , the number of dental plaque removal procedures decreased by an average of $10 \%$, a drastic decrease occurred at the age of 70-79 - only $10 \%$ of procedures were dental plaque removal procedures. Among women aged 30-59 who were patients of the clinic, the percentage of women with dental plaque removal was about $30 \%$, only in the age group over 80 the percentage of women who underwent the procedure fell to less than $10 \%$.

CONCLUSIONS. The results of the study show that the sex and age of the inhabitants of the Lomża region are significant variables related to the procedures of removing plaque in a dental office. Observation showing a decrease in the number of these procedures with increasing age of patients and their more frequent occurrence in women generally requires detailed studies identifying the main determinants of existing relationships.
\end{abstract}

Key words: dental plaque, prophylaxis of oral cavity diseases, periodontal disease 


\section{STRESZCZENIE}

WSTĘP. Narodowy Fundusz Zdrowia gwarantuje osobom ubezpieczonym bezpłatne leczenie stomatologiczne. Wśród usług stomatologicznych znajduje się zabieg usuwania złogów nazębnych, który można wykonywać u dorosłych 1 raz w ciągu 12 miesięcy lub 1 raz na 6 miesięcy w przypadku kobiet w ciąży i połogu. Procedura ta polega na rozbiciu biofilmu bakteryjnego nad- i poddziąsłowego, wypłukanie go wraz z wodą z okolicy przyzębia, a dodatkowo, poprzez efekt kawitacji, wywołuje implozję pęcherzyków powietrza bezpośrednio niszcząc komórki bakteryjne.

MATERIALY I METODY. Analiza objęła 2114 pacjentów w wieku 18-89 lat, którzy odbyli wizytę u dentysty od 01.01.2019 do 31.12.2019. Poradnia stomatologiczna mieściła się w średnim mieście w województwie podlaskim. Procedury usuwania złogów nazębnych były wykonywane przez lekarzy dentystów, a następnie kodowane zgodnie ze słownikiem ICD9 - Basic Edition Dictionary ICD9 CM (5.18) odpowiednio „23.1601 Usuwanie złogów nazębnych z 1/2 łuku zębowego ". Wizyty poddane analizie na potrzeby tego badania zostały wykonane w okresie od 01.01.2019 do 31.12.2019. W poniższym badaniu epidemiologicznym opisowym wykorzystano wtórne źródła informacji, w postaci zbiorczych raportów wygenerowanych z dokumentacji elektronicznej, która znajduje się w zasobach poradni stomatologicznej sprawującej opiekę dentystyczną nad pacjentami na podstawie umowy z Narodowym Funduszem Zdrowia na ogólne leczenie stomatologiczne.

WYNIKI. Całkowita liczba kobiet poddawanych procedurze usuwania złogów nazębnych była istotnie wyższa niż liczba mężczyzn. Rozkład pacjentów w poszczególnych grupach wieku był nierównomierny. Największy odsetek pacjentów z wykonaną procedurą usuwania złogów nazębnych wystąpił w grupach wiekowych 18-29 lat i 30-39 lat - odpowiednio 21\% i 29\% wszystkich pacjentów. Najmniejszą liczbę pacjentów stwierdzono w grupie wiekowej 80-89 lat (1\%). Istnieje statystyczna różnica w całkowitej liczbie zabiegów dentystycznych oraz w poszczególnych grupach wiekowych na korzyść kobiet w każdej grupie, z wyjątkiem przedziału wiekowego 60-79 lat. Najwięcej zabiegów usuwania złogów nazębnych w porównaniu z innymi zabiegami przeprowadzono u mężczyzn w wieku 30-39 lat. Wśród mężczyzn wraz ze wzrostem wieku aż do 60. roku życia liczba zabiegów usunięcia złogów nazębnych spadała średnio o 10\%. Większy spadek nastąpił w wieku 70-79 lat - tylko 10\% zabiegów było zabiegiem usuwania złogów nazębnych. Wśród kobiet w wieku 30 - 59 lat, które były pacjentkami poradni, odsetek kobiet z wykonanym zabiegiem usuwania złogów nazębnych wyniósł około $30 \%$, dopiero w przedziale wiekowym powyżej 80 lat odsetek kobiet z odbytym zabiegiem spadł do poziomu poniżej $10 \%$.

WNIOSKI. Wyniki badania pokazują, że płeć oraz wiek mieszkańców Łomży i okolic są istotnymi zmiennymi powiązanymi z procedurami usuwania złogów nazębnych w gabinecie stomatologicznym. Obserwacja wskazująca na spadek liczby tych zabiegów wraz ze wzrostem wieku pacjentów oraz ich częstsze występowanie u kobiet ogólnie wymaga szczegółowych badań identyfikujących przyczyny istniejących związków.

Slowa kluczowe: złogi nazębne, profilaktyka chorób jamy ustnej, choroby przyzębia

\section{INTRODUCTION}

The oral cavity is inhabited by about 700 species of bacteria. Some of them have their ecological niche on the supragingival and subgingival surfaces of patients' teeth and are part of dental deposits. In the case of non-compliance with the hygiene recommendations, as well as the host's compliance, there is a microbial shift towards gramm-negative aerobic and anaerobic bacteria. By producing endotoxins, exotoxins and metabolic products, microorganisms destroy nearby tissues, both directly and indirectly. (1) Additionally, when both bacteria and their products enter the bloodstream, some patients may deteriorate their health or respond to treatment of general diseases. This contributes to extending the treatment time and increasing costs for the patient and the payer.

\section{WSTĘP}

Jama ustna jest zasiedlana przez około 700 gatunków bakterii. Część z nich swoją niszę ekologiczną ma na powierzchniach naddziąsłowyh oraz poddziąsłowych uzębienia pacjentów i wchodzą w skład złogów nazębnych. W przypadku nieprzestrzegania zaleceń higienizacyjnych, a także podatności gospodarza dochodzi do przesunięcia mikrobiologicznego w kierunku gram-ujemnych bakterii tlenowych i beztlenowych. Drobnoustroje poprzez wytwarzanie endotoksyn, egzotoksyn oraz produktów przemiany materii niszczą okoliczne tkanki w sposób bezpośredni i pośredni (1). Dodatkowo, wraz z dostaniem się do krwioobiegu zarówno bakterii, jak i ich produktów u części pacjentów może dochodzić do pogorszenia stanu zdrowia lub słabszej odpowiedzi na leczenie chorób ogól- 
A healthy periodontium has a significant impact on the maintenance of an efficient masticatory system and overall health. There is evidence of a close relationship between periodontal disease and the incidence of cardiovascular disease, dysglycemia, and insulin resistance $(2,3)$. Appropriate home and professional prophylactic procedures are an effective way to reduce the number of bacteria and thus minimize the risk of inflammation. patients with therapeutic and prophylactic treatments of oral diseases. The plaque removal procedure performed during a dental visit is aimed at reducing the inflammatory response, primarily by eliminating bacterial plaques (4).This procedure involves breaking down the bacterial biofilm above and below the gingiva, rinsing it in vases with water from the periodontal area, and additionally, through the cavitation effect, it causes the implosion of air bubbles, directly destroying bacterial cells. (5) The procedure is safe, with a small number of possible complications and existing contraindications in healthy patients. However, transient bacteremia that occurs during the procedure, may lead to serious complications among generally burdened people. Certain cardiac diseases, such as cyanotic heart disease or valve prolapse, require appropriate preparation for dental procedures, including the risk of developing endocarditis. For this reason, in certain clinical cases, this procedure is contraindicated or an antibiotic cover is necessary. $(8,10)$.

Removal of plaque is part of the guaranteed health care services with the option to be performed once every 12 months for women and men without age limits, for pregnant women and once every 6 months during the puerperium. The National Health Fund, which is the payer of the Polish health care system, finances health services provided to insured persons. In 2019, in the Podlaskie Voivodeship, the National Health Fund concluded 271 contracts for dental treatment(9).

The contracts provide free treatment of oral diseases in nearly 1.2 million inhabitants of the Podlasie region.

\section{AIM OF THE STUDY}

The aim of the study was to assess the profile of adult patients receiving plaque removal at a dental clinic located in a medium-sized city in PodlaskieVoivodeship in the period from 01/01/2019 to $31 / 12 / 2019$. The work was created on the basis of medical data concerning treatments using electronic documentation. nych. Przyczynia się to do wydłużenia czasu leczenia i wzrostu kosztów po stronie pacjenta i płatnika.

Zdrowe przyzębie ma istotny wpływ na utrzymanie wydolnego narządu żucia, jak i ogólny stan zdrowia. Istnieją dowody na ścisły związek między chorobą przyzębia a występowaniem chorób sercowo -naczyniowych, dysglikemią oraz insulinoopornością $(2,3)$. Skutecznym sposobem na zmniejszenie liczby bakterii, a tym samym zminimalizowanie ryzyka stanu zapalnego, jest zastosowanie odpowiednich domowych i profesjonalnych procedur profilaktycznych. Z tego powodu wzrasta zainteresowanie pacjentów zabiegami leczniczymi oraz profilaktycznymi chorób jamy ustnej. Zabieg usuwania złogów nazębnych przeprowadzanych w trakcie wizyty stomatologicznej ma na celu zmniejszenie odpowiedzi zapalnej, przede wszystkim poprzez eliminację złogów bakteryjnych (4). Procedura ta polega na rozbiciu biofilmu bakteryjnego nad i poddziąsłowego, wypłukanie go wraz z wodą z okolicy przyzębia, a dodatkowo, poprzez efekt kawitacji, wywołuje implozję pęcherzyków powietrza bezpośrednio niszcząc komórki bakteryjne(5). Zabieg jest bezpieczny, z niewielką liczbą możliwych powikłań i istniejących przeciwwskazań u zdrowych pacjentów. Jednak przejściowa bakteriemia pojawiająca się w trakcie zabiegu może doprowadzić, wśród osób obciążonych ogólnie, do poważnych powikłań. Określone choroby kardiologiczne, takie jak sinicze wady serca lub wypadanie zastawek, wymagają odpowiedniego przygotowania do zabiegów stomatologicznych, między innymi ze względu na ryzyko powstania zapalenia wsierdzia. Z tego powodu w określonych przypadkach klinicznych zabieg ten jest przeciwwskazany lub niezbędna jest osłona antybiotykowa $(8,10)$.

Usuwanie złogów nazębnych jest częścią gwarantowanych usług opieki zdrowotnej z opcją wykonywania raz na 12 miesięcy dla kobiet i mężczyzn bez ograniczeń wiekowych, dla kobiet w ciąży oraz w okresie połogu raz na 6 miesięcy. Narodowy Fundusz Zdrowia, który jest płatnikiem polskiego systemu opieki zdrowotnej, finansuje usługi zdrowotne świadczone osobom ubezpieczonym. W 2019 r. w województwie podlaskim Narodowy Fundusz Zdrowia zawarł 271 umów na leczenie stomatologiczne (9). Kontrakty zapewniają bezpłatne leczenie chorób jamy ustnej u prawie 1,2 miliona mieszkańców regionu podlaskiego.

\section{CEL PRACY}

Celem badania była ocena profilu dorosłych pacjentów korzystających z zabiegu usuwania złogów nazębnych w poradni stomatologicznej zlokalizowanej w mieście o średniej wielkości w województwie podlaskim w okresie od 01.01.2019 r. do 31.12.2019 r. Praca powstała na podstawie danych medycznych 


\section{MATERIALS AND METHODS}

The analysis covered 2,114 patients aged 18-89 who visited the dentist from 01/01/2019 to 31/12/2019. The dental clinic was located in a medium-sized town in the PodlaskieVoivodeship. The dental plaque removal procedures were performed on patients by dentists, and then coded in accordance with the ICD9 Basic Edition Dictionary ICD9 CM (5.18) "23.1601 Removal of plaque from $1 / 2$ dental arch", respectively. During one visit, a maximum of 4 procedures may be performed. The study included the assessment of the following variables: the number of patients undergoing the dental plaque removal procedure, stratified by sex (female, male) and age group (7 age categories: under 18-29, 30-39, 40-49, 50-59, 60-69, 70-79, 80-89), mean age and median age of patients with a plaque removal procedure performed by gender, percentage of plaque removal procedures compared to all procedures by sex and age.

In the following epidemiological descriptive study, secondary sources of information were used, in the form of collective reports generated from electronic records, which are stored in the dental clinic that provides dental care for patients under an agreement with the National Health Fund for general dental treatment.

\section{RESULTS OF THE STUDY}

In the analyzed period, 577 patients admitted to the dental clinic underwent the dental plaque removal procedure ( $27 \%$ of all patients). The procedures were performed in 239 men ( $29 \%$ of all patients - men) and 338 women ( $26 \%$ of all women - patients). The total number of women undergoing the plaque removal procedure was significantly higher $(p<0,05)$ than the number of men $-41 \%$ of all procedures were performed in men and , respectively, 59\% - in women.

The distribution of patients in different age groups was uneven. The highest percentage of patients with the dental plaque removal procedure occurred in the age groups of $30-39$ and $40-49$ years $-39 \%$ and $23 \%$ of all patients, respectively. The lowest number of patients was found in the age group of 80-89 years (1\%). The youngest person under study was 18 years old; the oldest patient was 89 years old.

There is a statistical difference in the total number of dental procedures and in different age groups to the benefit of women in each group, except for the age group 60-79 years (the number of procedures for women and men did not differ significantly in this range).

In the 30-39 age group, 210 plaque removal procedures were performed in men $37 \%$ of all dotyczących zabiegów wykorzystując dokumentację elektroniczną.

\section{MATERIAŁ I METODY}

Analiza objęła 2114 pacjentów w wieku 18-89 lat, którzy odbyli wizytę u dentysty od 01.01.2019 r. do 31.12.2019 r. Poradnia stomatologiczna mieściła się w średnim mieście w województwie podlaskim. Procedury usuwania złogów nazębnych były wykonywane u pacjentów przez lekarzy dentystów, a następnie kodowane zgodnie ze słownikiem ICD9 - Basic Edition Dictionary ICD9 CM (5.18) odpowiednio „23.1601 - Usuwanie złogów nazębnych z 1/2 łuku zębowego ". Na jednej wizycie można wykazać maksymalnie 4 takie procedury. Badanie obejmowało ocenę następujących zmiennych: liczba pacjentów z wykonaną procedurą usuwania złogów nazębnych stratyfikowaną według płci (kobieta, mężczyzna) i grupy wiekowej (7 kategorii wiekowych: poniżej 18-29, 30-39, 40-49, 5059, 60-69, 70-79, 80-89 lat), średni wiek i mediana wieku pacjentów z wykonaną procedurą usuwania złogów nazębnych według płci, odsetek procedur usuwania złogów nazębnych w porównaniu do wszystkich zabiegów w podziale na płeć i wiek.

W poniższym epidemiologicznym badaniu opisowym wykorzystano wtórne źródła informacji, w postaci zbiorczych raportów wygenerowanych $\mathrm{z}$ dokumentacji elektronicznej, która znajduje się w zasobach poradni stomatologicznej sprawującej opiekę dentystyczną nad pacjentami na podstawie umowy z Narodowym Funduszem Zdrowia na ogólne leczenie stomatologiczne.

\section{WYNIKI}

W badanym okresie 577 pacjentów przyjętych w poradni stomatologicznej miało wykonaną procedurę usuwania złogów nazębnych $(27 \%$ wszystkich pacjentów). Zabiegi wykonane zostały u 239 mężczyzn (29\% wszystkich pacjentów - mężczyzn) i 338 kobiet (26\% wszystkich kobiet - pacjentów).Całkowita liczba kobiet poddawanych procedurze usuwania złogów nazębnych była istotnie wyższa $(p<0,05)$ niż liczba mężczyzn - 41\% wszystkich zabiegów było wykonanych u mężczyzn i, odpowiednio, 59\% - u kobiet.

Rozkład pacjentów w poszczególnych grupach wieku był nierównomierny. Największy odsetek pacjentów z wykonaną procedurą usuwania złogów nazębnych był w grupach wiekowych 30-39 lat i 40-49 lat, odpowiednio $39 \%$ i $23 \%$ wszystkich pacjentów. Najmniejszą liczbę pacjentów stwierdzono w grupie wiekowej 80-89 lat (poniżej 1\%). Najmłodsza badana osoba miała 18 lat; najstarszy pacjent miał 89 lat. 
plaque removal procedures in men and $42 \%$ of all dental procedures among men) and 408 plaque removal procedures in women $(41 \%$ of all plaque removal procedures in women and $34 \%$ of all dental procedures among women) - both in women and men it is the most numerous age subgroup, and there is the greatest difference between the two subgroups, as there are almost twice as many women as men in this age subgroup. The number of women in this subgroup also significantly influences the difference in the total number of women in relation to the total number of men and the difference in the gender median.

Also in the 70-79 age group, the number of women undergoing plaque removal was significantly higher than the number of men $(\mathrm{p}<0.05)$ - the percentage was $2 \%$ in men and $5 \%$ in women, respectively.

Most of the dental plaque removal procedures, compared to other procedures, were performed in men aged 30-39 years - 42\% of them underwent the procedure. Among men, as the age grew up to the age of 60 , the number of dental plaque removal procedures decreased by an average of $10 \%$, a drastic decrease occurred at the age of 70-79 - only $10 \%$ of procedures were dental plaque removal procedures.

Among women aged 30-59 who were patients of the clinic, the percentage of women with dental plaque removal was about $30 \%$, only in the age group over 80 the percentage of women who underwent the procedure fell to less than $10 \%$.

Table II shows the frequency of plaque removal in the population of patients in a dental surgery compared
Istnieje statystyczna różnica w całkowitej liczbie zabiegów dentystycznych oraz w poszczególnych grupach wiekowych na korzyść kobiet w każdej grupie, z wyjątkiem przedziału wiekowego 60-79 lat (w tym przedziale liczba zabiegów dla kobiet i mężczyzn nie różniła się istotnie).

W przedziale wiekowym 30 - 39 lat wykonano 210 zabiegów usuwania złogów nazębnych u mężczyzn (37\% wszystkich zabiegów usuwania złogów u mężczyzn i $42 \%$ wszystkich zabiegów stomatologicznych u mężczyzn oraz 408 zabiegów usunięcia złogów u kobiet (41\% wszystkich zabiegów usuwania złogów u kobiet i 34\% wszystkich zabiegów stomatologicznych u kobiet - zarówno u kobiet, jak i u mężczyzn jest to najliczniejsza podgrupa wiekowa, jak też występuje tu największa różnica między obiema podgrupami, jako że w tej podgrupie wiekowej znajduje się prawie dwa razy tyle kobiet co mężczyzn. Liczebność kobiet w tej podgrupie istotnie wpływa też na różnicę w całkowitej liczbie kobiet w stosunku do całkowitej liczby mężczyzn i różnicę w medianie wieku. Również w grupie wiekowej 70-79 lat liczba kobiet poddanych usunięciu złogów nazębnych była istotnie wyższa niż liczba mężczyzn $(p<0,05)$ - odsetek wyniósł odpowiednio 2\% u mężczyzn i 5\% u kobiet.

Najwięcej zabiegów usuwania złogów nazębnych $\mathrm{w}$ porównaniu $\mathrm{z}$ innymi zabiegami przeprowadzono u mężczyzn w wieku 30-39 lat - 42\% z nich miało wykonany zabieg. Wśród mężczyzn wraz ze wzrostem wieku aż do 60. roku życia liczba zabiegów usunięcia złogów nazębnych spadała średnio o 10\%, drastyczny

Table I Number of people with the plaque removal procedure by sex and age who admitted to the Dental Clinic in 2019: Tabela I. Liczba osób, u których wykonano procedurę usuwania złogów nazębnych według płci i wieku przyjętych w Poradni Stomatologicznej w 2019 roku.

\begin{tabular}{|c|c|c|c|c|c|c|}
\hline $\begin{array}{c}\text { Age group/ } \\
\text { Grupa wiekowa }\end{array}$ & $\begin{array}{c}\text { Men/ } \\
\text { Mężczyźni } \\
\text { n }\end{array}$ & $(\%)$ & $\begin{array}{c}\text { Women/ } \\
\text { Kobiety } \\
\text { N }\end{array}$ & $(\%)$ & $\begin{array}{c}\text { Total/ } \\
\text { Razem }\end{array}$ & $(\%)$ \\
\hline $18-29$ & 28 & $12 \%$ & 40 & $12 \%$ & 68 & $12 \%$ \\
\hline $30-39 *$ & 88 & $37 \%$ & 139 & $41 \%$ & 227 & $39 \%$ \\
\hline $40-49$ & 62 & $26 \%$ & 69 & $20 \%$ & 131 & $23 \%$ \\
\hline $50-59$ & 31 & $13 \%$ & 42 & $12 \%$ & 73 & $13 \%$ \\
\hline $60-69$ & 25 & $10 \%$ & 30 & $9 \%$ & 55 & $10 \%$ \\
\hline $70-79 *$ & 4 & $2 \%$ & 17 & $5 \%$ & 21 & $4 \%$ \\
\hline $80-89$ & 1 & $0 \%$ & 1 & $0 \%$ & 2 & $0 \%$ \\
\hline Total/ Razem & 239 & $100 \%$ & 338 & $100 \%$ & 577 & $100 \%$ \\
\hline $\begin{array}{c}\text { Dental plague removal percentage } \\
(\%) / \\
\text { Usuwanie złogów nazębnych } \\
\text { a płeć }(\%)\end{array}$ & $41 \%$ & & $59 \%$ & $100 \%$ & & \\
\hline $\begin{array}{l}\text { mean (standard deviation)/ } \\
\text { średnia (odchylenie standardowe) }\end{array}$ & 43 (13) & & $43(14)$ & & & \\
\hline
\end{tabular}

* statistically significant differences in subgroups by sex with $\mathrm{p}<0.05$

* istotne statystycznie różnice w podgrupach w podziale według płci przy $\mathrm{p}<0,05$ 
Table II.The percentage of the number of dental clinic patients with plaque removal compared to all dental procedures by gender and age in 2019

Tabela II. Odsetek liczby pacjentów poradni dentystycznej z wykonanym zabiegiem usuwania złogów nazębnych w porównaniu do wszystkich zabiegów stomatologicznych w zależności od płci oraz wieku w 2019 roku.

\begin{tabular}{|c|c|c|c|c|c|}
\hline $\begin{array}{c}\text { Age Group/ } \\
\text { Grupa } \\
\text { wiekowa }\end{array}$ & $\begin{array}{l}\text { Total number of } \\
\text { men visiting the } \\
\text { dentist/ } \\
\text { Całkowita } \\
\text { liczba mężczyzn } \\
\text { odwiedzających } \\
\text { dentystę }\end{array}$ & $\begin{array}{c}\text { (\%)the share } \\
\text { of dental } \\
\text { plaque removal } \\
\text { treatments among } \\
\text { all treatments/ } \\
(\%) \text { udział } \\
\text { zabiegów } \\
\text { usuwania złogów } \\
\text { nazębnych spośród } \\
\text { wszystkich } \\
\text { zabiegów }\end{array}$ & $\begin{array}{l}\text { Total number of } \\
\text { women visiting } \\
\text { the dentist/ } \\
\text { Całkowita } \\
\text { liczba kobiet } \\
\text { odwiedzających } \\
\text { dentystę }\end{array}$ & $\begin{array}{c}\text { (\%)the share } \\
\text { of dental } \\
\text { plaque removal } \\
\text { treatments among } \\
\text { all treatments/ } \\
(\%) \text { udział } \\
\text { zabiegów } \\
\text { usuwania złogów } \\
\text { nazębnych spośród } \\
\text { wszystkich } \\
\text { zabiegów }\end{array}$ & $\begin{array}{c}\text { Total/ } \\
\text { Razem }\end{array}$ \\
\hline $18-29 *$ & 171 & $16 \%$ & 268 & $15 \%$ & 439 \\
\hline $30-39 *$ & 210 & $42 \%$ & 408 & $34 \%$ & 618 \\
\hline $40-49 *$ & 169 & $37 \%$ & 232 & $30 \%$ & 401 \\
\hline $50-59 *$ & 103 & $30 \%$ & 157 & $27 \%$ & 260 \\
\hline $60-69$ & 119 & $21 \%$ & 139 & $22 \%$ & 258 \\
\hline $70-79^{*}$ & 40 & $10 \%$ & 77 & $22 \%$ & 117 \\
\hline $80-89$ & 8 & $13 \%$ & 13 & $8 \%$ & 21 \\
\hline Total/ Razem & 820 & $29 \%$ & 1294 & $26 \%$ & 2114 \\
\hline
\end{tabular}

* statistically significant differences in the number of subgroups by sex with $\mathrm{p}<0.05$

* statystycznie istotne różnice w liczebności podgrup w podziale na płeć przy $\mathrm{p}<0,05$

to all dental procedures depending on the patient's sex and age.

The mean age of men and women who underwent professional plaque removal in the sample was 43 years, and the difference was not statistically significant. The median age of men undergoing the procedure was 45 years and was significantly higher than the median

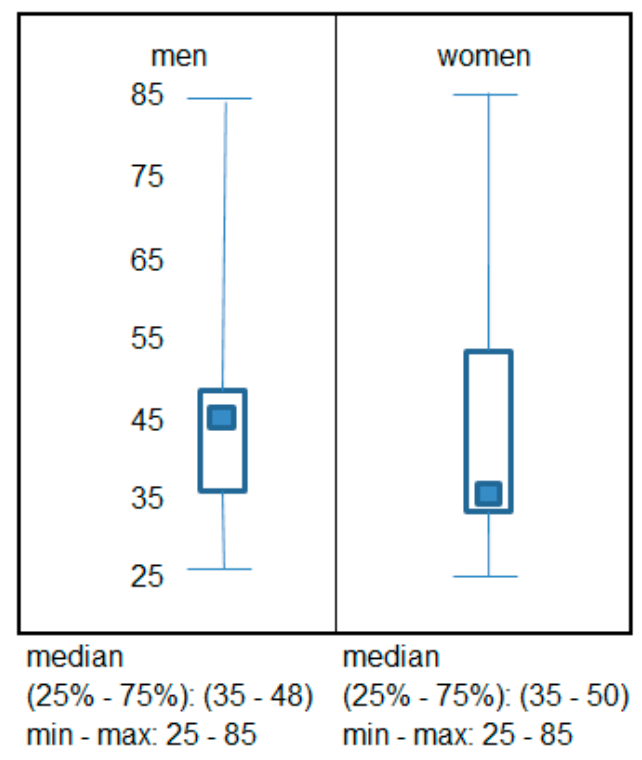

Figure1: Median and IQR age of persons undergoing plaque removal by sex.

Rycina 1. Mediana oraz IQR wieku osób, u których wykonano zabieg usuwania złogów nazębnych według płci. spadek nastąpił w wieku 70-79 lat - tylko 10\% zabiegów było zabiegiem usuwania złogów nazębnych.

Wśród kobiet w wieku 30-59 lat, które były pacjentkami poradni, odsetek kobiet $\mathrm{z}$ wykonanym zabiegiem usuwania złogów nazębnych wyniósł około $30 \%$, dopiero w przedziale wiekowym powyżej 80 lat odsetek kobiet z odbytym zabiegiem spadł do poziomu poniżej $10 \%$.

Częstość wykonania usuwania złogów nazębnych w populacji pacjentów w gabinecie stomatologicznym w porównaniu do wszystkich zabiegów stomatologicznych w zależności od płci i wieku pacjenta pokazano w tabeli II.

Średni wiek mężczyzn i kobiet, którzy przeszli zabieg profesjonalnego usuwania złogów nazębnych w próbie, wynosił 43 lata i różnica nie była statystycznie istotna. Mediana wieku mężczyzn korzystających $\mathrm{z}$ zabiegu wynosiła 45 lat i była istotnie wyższa od mediany wieku kobiety (35 lat). Oznacza to, że młode kobiety były częściej zainteresowane profesjonalnym usuwaniem złogów nazębnych niż mężczyźni.

Rycina 1 przedstawia rozkład wieku osób z wykonaną procedurą usuwania złogów nazębnych według płci.

U mężczyzn mediana wieku wykonania zabiegu usuwania złogów nazębnych zbliżona jest do średniej - niewielu mężczyzn bardzo młodych oraz po 70 r.ż. miało przeprowadzonych zabieg, podczas gdy w badaniu znalazła się duża liczba kobiet - pacjentek 
age of the woman (35 years). This means that young women were more interested in professional plaque removal than men.

Figure 1 presents distribution of age of people with a dental plaque removal procedure by gender.

In men, the median age of the dental plaque removal procedure is close to the average - there were very few very young and men over 70 years who underwent the procedure, while the study included a large number of women - patients with plaque removal in the 70-79 age group.

\section{DISCUSSION}

In Poland, in 2018 there were 3.9 thousand. dental offices that provided treatment services financed from public funds. The number of dental consultations at that time amounted to 34.4 million, which accounted for approximately $11 \%$ of all medical consultations. According to data from 2018, one resident of the Podlaskie voivodship had one dental visit(10).Considering that, according to medical recommendations, regular dental checkups should be performed to maintain oral health, the intervals between visits should be kept short, and a professional plaque removal procedure should be performed at least once a year, the data are alarmingly low $(11,12)$.

Professional removal of dental plaque is one of the preventive and therapeutic procedures that play a key role in preventing diseases occurring in the oral cavity. By minimizing the burden of pathogenic bacteria, it reduces the likelihood of tooth decay and gingivitis, which, if left untreated, can cause periodontitis $(13,14,15)$.

Hygienic procedures such as plaque removal are included in the first, causal, therapeutic phase of these diseases(16).

Nationwide studies confirm the conclusions of this study that the number of preventive dental procedures performed on patients decreases with age. Advice provided to people aged 65 and older accounted for $15.2 \%$ of preventive dental procedures; in the countryside, these indicators were $1.9 \mathrm{pp}$ lower (19).

The greater number of groups of young people up to 49 years of age in prophylactic procedures (such as the removal of dental plaque), which has been demonstrated in this study, is also confirmed by surveys among dentistry students. They indicate that younger age groups are more aware of the importance of prophylactic behavior in maintaining health until old age. Factors having a large impact on health status included proper health behavior and regular check-ups, including dental visits to remove plaque $(23,24,25)$.

A limitation of this study is the exclusion of "patient paid" visits, which may have had an impact z wykonanym zabiegiem usuwania złogów nazębnych w przedziale wieku 70-79 lat.

\section{DYSKUSJA}

W Polsce w roku 2018 było zarejestrowanych 3,9 tys. gabinetów stomatologicznych, które realizowały usługi lecznicze finansowane ze środków publicznych. Liczba konsultacji dentystycznych wyniosła w tym czasie $34,4 \mathrm{mln}$ i stanowiło to około $11 \%$ wszystkich konsultacji medycznych. Według danych z 2018 r. w województwie podlaskim na jednego mieszkańca przypadała jedna wizyta stomatologiczna (10). Dane są niepokojąco niskie biorąc pod uwagę, że zgodnie $\mathrm{z}$ zaleceniami lekarskimi $\mathrm{w}$ celu zachowania zdrowia jamy ustnej należy przeprowadzać regularne kontrole stomatologiczne, odstępy między wizytami powinny być krótkie, a co najmniej raz w roku należy wykonywać zabieg profesjonalnego usuwania złogów nazębnych, $(11,12)$.

Profesjonalne usunięcie złogów nazębnych należy do procedur profilaktycznych oraz leczniczych, które odgrywają kluczową rolę w zapobieganiu chorobom występującym w jamie ustnej. Minimalizując obciążenie bakteriami chorobotwórczymi, redukuje się prawdopodobieństwo powstania próchnicy zębów i pojawienia się zapalenia dziąseł, które nieleczone może powodować zapalenie przyzębia(13-15).Procedury higieniczne takie jak usuwanie złogów nazębnych są uwzględnione w pierwszej, przyczynowej fazie terapeutycznej tych chorób (16).

Badania ogólnopolskie potwierdzają wnioski niniejszego badania, że wraz z wiekiem maleje liczba wykonywanych u pacjentów profilaktycznych zabiegów stomatologicznych. Porady udzielane osobom w wieku 65 lat i starszym stanowiły 15,2\% profilaktycznych zabiegów dentystycznych; na wsi wskaźniki te były o 1,9 punktów procentowych mniejsze (19).

Większą liczebność grup młodych do 49 roku życia w zabiegach profilaktycznych (takich jak usuwanie złogów nazębnych), która została wykazana w niniejszym badaniu, potwierdzają też ankiety przeprowadzone wśród studentów stomatologii. Wskazują one, że młodsze grupy wiekowe są bardziej świadome znaczenia zachowań profilaktycznych dla zachowania zdrowia do starości. Wśród czynników mających duży wpływ na stan zdrowia wymieniono prawidłowe zachowania zdrowotne i regularne wizyty kontrolne, w tym wizyty dentystyczne w celu usunięcia złogów nazębnych (23-25).

Ograniczeniem niniejszego badania jest wyłączenie wizyt „opłacanych przez pacjenta”, co mogło mieć wpływ na wyniki badania. Dodatkowo, charakter użytych danych jest podatny na niekompletne lub nieprawidłowe zapisy medyczne i kodowanie. Spadek li- 
on the study results. Additionally, the nature of the data used is prone to incomplete or incorrect medical records and coding. The decline in the number of patients with age observed in this study is also confirmed by data on outpatient health care in 2018 presented by the Central Statistical Office. In 2018, $56 \%$ of all dental consultations were registered among the Polish population aged 18-64, while the percentage of consultations provided to people aged 65 and over was $15.5 \%(10)$.

Both the above analysis and scientific publications analyzing the nationwide data confirm that women more often care for the prevention of oral diseases than men. Women in cities accounted for $55.3 \%$ of the total number of dental clinic patients $(0.3 \mathrm{pp}$ less than in 2016) (19).

The disproportions in the frequency of dental plaque removal procedures in favor of women are also confirmed by other analyzes in studies conducted in the Łódź Province. Women significantly more often underwent dental plaque removal than men (70.9 vs. $29.1 \%)$ and $(58.57 \%$ vs. $41.43 \%)(17,18)$.

Differences in the use of medical services among men and women are visible not only in preventive dental procedures, dental treatment in general, but also in specialist medical care, hospital treatment, psychiatric care and therapeutic rehabilitation $(20,21)$. Women in Poland not only use medical care more often, but are also more aware than men of the importance of prophylaxis in maintaining health(22).

The analysis of the patient profile of the Łomża region showed that the gender differences in the age groups over 60 were no longer statistically significant, so a similar number of patients visited the dentist, while the percentage of reports compared to other treatment methods was significantly different - the number of dental plaque removal treatments decreased to a greater extent among men. Older men, if they already visited the dentist, were to perform other procedures, while women could come to the dentist only to remove plaque. It seems likely that fewer procedures of this type may be associated with progressive tooth loss (26,27).Toothlessness excludes the possibility of removing dental plaque. Among the male population of 89 in a nursing home in Brazil, the mean patient age was 75.9 years, while the mean tooth count was 3.9(28).In Poland, as part of the study of the population of Wrocław, it was found that $21.1 \%$ of the surveyed residents aged 65 and older were toothless(29).Similarly negative results were obtained in Georgia among seniors. Among 300 residents of nursing homes in Georgia, toothlessness was found in $36.2 \%$ of residents(30).Korean research indicates that male gender is also one of the factors that negatively affects the number of teeth in old age (OR: 0.74)(31). czebności pacjentów wraz z wiekiem zaobserwowany w badaniu potwierdzają też dane dotyczące ambulatoryjnej opieki zdrowotnej w 2018 roku przedstawione przez Główny Urząd Statystyczny. Wśród polskiej populacji w $2018 \mathrm{r}$. w wieku 18-64 lat zarejestrowano $56 \%$ wszystkich porad stomatologicznych, podczas gdy odsetek porad udzielonych osobom w wieku 65 lat i starszych wynosił $15,5 \%$ (10).

Zarówno przeprowadzona powyżej analiza, jak i publikacje naukowe analizujące dane ogólnopolskie potwierdzają, że kobiety częściej dbają o profilaktykę chorób jamy ustnej niż mężczyźni. Kobiety w miastach stanowiły 55,3\% ogólnej liczby pacjentów poradni stomatologicznych (o 0,3 pkt. procentowego mniej niż w 2016 r.) (19).

Dysproporcje częstości wykonania zabiegów usuwania złogów nazębnych na korzyść kobiet potwierdzają też inne analizy w badaniach przeprowadzonych w województwie łódzkim. Kobiety istotnie częściej miały wykonany zabieg usuwania złogów nazębnych niż mężczyźni (70,9 vs. $29,1 \%)$ i $(58,57 \%$ vs $41,43 \%)$ $(17,18)$.

Różnice w korzystaniu z usług medycznych wśród mężczyzn i kobiet są widoczne nie tylko w profilaktycznych zabiegach stomatologicznych, leczeniu stomatologicznym ogólnie, ale także w specjalistycznej opiece medycznej, leczeniu szpitalnym, opiece psychiatrycznej i rehabilitacji terapeutycznej $(20,21)$. Kobiety w Polsce nie tylko częściej korzystają z opieki medycznej, ale również bardziej niż mężczyźni są świadome znaczeniaprofilaktyki w utrzymaniu zdrowia (22).

Analiza profilu pacjentów regionu łomżyńskiego wykazała, że różnice płci w grupach wiekowych powyżej 60 roku życia nie były już statystycznie istotne, więc podobna liczba pacjentów odwiedziła dentystę, podczas gdy odsetek zgłoszeń w porównaniu z innymi metodami leczenia istotnie się różnił - liczba zabiegów usuwania złogów nazębnych zmniejszyła się w większym stopniu wśród mężczyzn. Starsi mężczyźni, jeśli już pojawili się u dentysty, to w celu wykonywania innych zabiegów, podczas gdy kobiety mogły przyjść do stomatologa jedynie w celu wykonania usunięcia złogów nazębnych. Wydaje się prawdopodobne, że mniejsza liczba tego typu procedur może być związana z postępującą utratą zębów $(26,27)$. Bezzębie wyklucza możliwość wykonywania zabiegów usuwania złogów nazębnych. Wśród populacji 89 mężczyzn w domu opieki w Brazylii średni wiek pacjenta wynosił 75,9 roku, podczas gdy średnia liczba zębów wynosiła 3,9 (28). W Polsce w ramach badania populacji Wrocławia stwierdzono, że $21,1 \%$ badanych mieszkańców w wieku 65 lat i starszych było bezzębnych (29). Podobnie negatywne wyniki uzyskano w Gruzji wśród seniorów. Wśród 300 mieszkańców domów opieki w Gruzji 
Among the studied population of the Łomża region, low attendance of men for visits compared to women and less frequent prophylactic procedures, first in the younger age groups, and then in the oldest ones, may suggest that there may be similar relationships among the respondents, which may have an impact on the results of the analysis. However, confirming this hypothesis would require in-depth research.

\section{CONCLUSION}

The results of the study show that the sex and age of the inhabitants of the Łomża region are significant variables related to the procedures of removing plaque in a dental office. Observation showing a decrease in the number of performance of these procedures with increasing age of patients and their more frequent occurrence in women requires detailed studies identifying the causes of existing relationships.

\section{REFERENCES}

1. Rosier BT, Marsh PD, Mira A. Resilience of the Oral Microbiota in Health: Mechanisms That Prevent Dysbiosis. J Dent Res. 2018, 97 (4): 371 $-380$.

2. Sanz M, Ceriello A, Buysschaert M, et al. Scientific evidence on the links between periodontal diseases and diabetes: Consensus report and guidelines of the joint workshop on periodontal diseases and diabetes by the International Diabetes Federation and the European Federation of Periodontology. J ClinPeriodontol. 2018;45(2):138-149.

3. Peng CH, Yang YS, Chan KC, Kornelius E, Chiou JY, Huang CN. Periodontal Treatment and the Risks of Cardiovascular Disease in Patients with Type 2 Diabetes: A Retrospective Cohort Study. Intern Med. 2017;56(9):1015-1021.

4. Manresa C, Sanz-Miralles EC, Twigg J, Bravo M. Supportive periodontal therapy (SPT) for maintaining the dentition in adults treated for periodontitis. Cochrane Database Syst Rev. 2018;1(1):CD009376.

5. Vyas N, Dehghani H, Sammons RL, Wang QX, Leppinen DM, Walmsley AD. Imaging and Analysis of Individual Cavitation Microbubbles around Dental Ultrasonic Scalers. Ultrasonics. 2017; 81: 66-72

6. Mask AG Jr. Medical management of the patient with cardiovascular disease. Periodontol 2000. 2000;23:136-141.

7. Kapłon-Cieślicka A, Napora M, Grabowski M et al., Prevention of infective endocarditis before dental procedures.Nowa Stomatologia 2008;3:121126. bezzębność stwierdzono u 36,2\% mieszkańców (30). Koreańskie badania wskazują, że płeć męska jest również jednym z czynników negatywnie wpływających na liczbę zębów w starszym wieku (OR: 0,74) $(31)$. Wśród badanej populacji mieszkańców regionu łomżyńskiego niska zgłaszalność mężczyzn na wizyty w porównaniu do kobiet i rzadsze zabiegi profilaktyczne, najpierw w młodszych grupach wiekowych, a następnie w najstarszych mogą sugerować, że wśród badanych mogą występować podobne relacje, co może mieć wpływ na wynik analizy. Potwierdzenie tej hipotezy wymagałoby jednak pogłębionych badań.

\section{WNIOSKI}

Wyniki badania pokazują, że płeć oraz wiek mieszkańców Łomży i okolic są istotnymi zmiennymi powiązanymi z procedurami usuwania złogów nazębnych w gabinecie stomatologicznym. Obserwacja wskazująca na spadek liczby tych zabiegów wraz ze wzrostem wieku pacjentów oraz ich częstsze wykonywanie u kobiet wymaga szczegółowych badań identyfikujących przyczyny istniejących związków.

8. Folwaczny M, Wilberg S, Bumm C, et al. Oral Health in Adults with Congenital Heart Disease. J Clin Med. 2019;8(8):1255. Published 2019 Aug 19. doi: $10.3390 / \mathrm{jcm} 8081255$.

9. List of healthcare providers for 2019 in the PodlaskieVoivodeship, webside https://aplikacje. nfz.gov.pl/umowy/. access 04.01.2020.

10. Sańka A, Out-patient health care in 2018. Statistical Office in Krakow Center for Health Statistics and Health Care. access from www.stat.gov.pl 13.01.2020.

11. Linden J, Josefsson K, Widström E. Frequency of visits and examinations in the Public Dental Service in Finland - a retrospective analysis, 2001-2013, BMC Oral Health. 2017; 17: 138.https:// doi.org/10.1186/s12903-017-0436-8.

12. Ganss C, Heins M, Schlueter N.An oral care programme for adults- Evaluation after 15 years. PLoS One. 2019;5;14(12):e0223960. doi: 10.1371/ journal.pone.0223960. access 14.01.2020 .

13. Kwon T, Salem DM, Levin L. Nonsurgical periodontal therapy based on the principles of cause-related therapy: rationale and case series. Quintessence Int 2019;50(5):370-376.

14. Lamont T, Worthington HV, Clarkson JE et al. Routine scale and polish for periodontal health in adults. Cochrane Database Syst Rev. 2018(12) 27; doi: 10.1002/14651858.CD004625.pub5.

15. Kinane DF, Stathopoulou PG, Papapanou PN. Periodontal diseases. Nat Rev Dis Primers. 2017(6)22;3:17038. doi: 10.1038/nrdp.2017.38. 
16. Zaremba M, Czerniuk MR, Górska R. Surgical treatment of severe periodontitis as an alternative to implantological treatment - two case reports, Nowa Stomatologia 2012;4: 180-185.

17. Hilt A, Rybarczyk-Townsend E. LubowiedzkaGontarek B. Oral Health Problems of 35-44Year Old Inhabitants of The Lodz Region.Przegl. Epidemiol 2012; 66: 133 - 138.

18. Sopińska K, Olszewska N, Bołtacz-Rzepkowska E. The effect of dental anxiety on the dental status of adult patients in the Lodz region. Dent Med Probl. 2017;26(1):73-78.

19. Żyra M, Malesa E. Health and health care in 2017, Statistics Poland, Social Surveys Department, Statistical Office in Kraków, Health Statistics Division, Centre for Health and Health Care Statistics, 79-89/2018, ISSN 2084-0470 www.stat. gov.pl access 13.01.19.

20. Schlichthorst M, Sanci LA, Pirkis J et al. Why do men go to the doctor? Socio-demographic and lifestyle factors associated with healthcare utilisation among a cohort of Australian men. BMC Public Health. 2016;31;16(Suppl 3):1028.

21. M Bujnowska-Fedak, BJ. Sapilak, A Steciwko. Epidemiology of diseases and structure of morbidity in family medicine practice, Family Medicine \& Primary Care Review. 2011;13; 2: 135-139.

22. Korporowicz V, Differences in health behaviors and costs of treatment of men and women in Poland. Kwartalnik Kolegium Ekonomiczno-Społecznego Studia i Prace, Szkoła Główna Handlowa 2013;3: 79-100.

23. Gładczuk J, Karczewska B, Wojszko A et al. Socio-health conditions of dental prophylaxis among students of Państwowa Wyższa Szkoła Zawodowa w Suwałkach. Medycyna Ogólna i Nauki o Zdrowiu.2016; 22(4): 282-286.

24. Knaś M, Zalewska A, Kleszczewski T et al. Prohealth attitudes of students of selected Polish, Belarus and Ukraine universities concerning control dental examinations. Hygeia Public Health. 2015;50(3): 507-513.

25. Śniatała R. Dental health-promoting behavior of American and Polish academic youth, Work for the degree of doctor of medical sciences, Uniwersytet Medycznyim. Karola Marcinkowskiego w Poznaniu Katedra i Klinika Stomatologii Dziecięcej, 2011.

26. Ortíz-Barrios LB, Granados-García V, CruzHervert $\mathrm{P}$ et al. The impact of poor oral health on the oral health-related quality of life (OHRQoL) in older adults: the oral health status through a latent class analysis.BMC Oral Health. 2019;10;19(1):141.

27. Górska R, Górski B. Self-reported oral status and habits related to oral care in adult Poles: A questionnaire study.Dent Med Probl. 2018;55(3):313-320.

28. Mendes MSS, Chester LN, Fernandes Dos Santos JF. Self-perceived oral health among institutionalized older adults in Taubate, Brazil. Spec Care Dentist. 2020;40(1):49-54.

29. Oral health and the quality of life of elderly people, edited by. prof. dr hab. U Kaczmarek, Medical University of Wrocław, Chair and Department of Conservative and Pediatric Dentistry, Wrocław 2018:83-99 ISBN 978-83-7055-327-2.

30. Puturidze S, Margvelashvili M, Bilder L. Correlation Of Oral Health Status With General Health In Elderly Living At Residential Homes In Georgia. Georgian Med News. 2019;(292-293):2125.

31. Lee JH, Yi SK, Kim SY et al. Factors Related to the Number of Existing Teeth among Korean Adults Aged 55-79 Years. International journal of environmental research and public health 2019;16(20), 3927. https://doi.org/10.3390/ ijerph16203927.

Received: 24.04.2020

Accepted for publication: 14.09 .2020

Otrzymano:24.04.2020 r.

Zaakceptowano do publikacji: 14.09.2020 r.

\section{Address for correspondence: Adres do korespondencji:}

Katarzyna Czechowska

Centrum Stomatologiczne Demed Sp. z o.o.

Słowackiego 7a, 18-400 Łomża

Tel: +48 501198687

e-mail: katarzyna.czechowska@gmail.com 